\title{
RUSSIA AND THE EUROPEAN UNION'S NEW MEMBER STATES: THEIR COOPERATION AND RIVALRY IN THE FIELD OF ENERGY
}

\author{
by Sylwester Gardocki
}

\section{RUSSIA'S STATUS AS A WORLD POWER}

Relations between Russia and the European Union are particularly important in the sphere of the production, transmission and use of energy resources as it is in this field where Russia possesses its key strategic assets, and the European Union heavily relies on supplies of oil and natural gas from this country. Russia wants to be perceived as a superpower by the European Union countries and believes that having such a status will contribute to its further progress. In order to accomplish this goal it should take advantage of its superior position in the field of power industry. In the past, both in the times of czarism and the Soviet Union, Imperial Russia built its status as a world power primarily by using its military potential to expand its territory. We compare this tradition to Russia's present attitude, the latter is undoubtedly less dangerous and it may become the basis for mutually advantageous cooperation. It does not imply that Russia's policy does not cause concern any longer, but this fear is of a different nature and can be dealt with through peaceful methods, such as well managed diplomacy that will provide legal framework, specific investment projects carried out in areas of common interest, or collaboration towards solving problems 
of energy security and settling environmental issues not only in the European Union, but also in the whole European continent.

\section{RUSSIAN POTENTIAL AND THE STRATEGY PRINCIPLES}

In order to understand why the attitudes of the European Union elites towards Russia are the mixture of fear and hope for harmonious coexistence, a few fundamental facts must be reminded. Firstly, the collapse of the Soviet Union was a peaceful process despite the fact that this country was a military superpower which constantly armed itself. Thus, the fact that Russia has gathered enormous arsenal does not have to imply that it is a threat to other nations. However, the memory of the times of Russia's military world power status still lives on in Europe, especially in Central and Eastern Europe and the Balkans. Contemporary Russia is a historical heir to both failures and successes of the Soviet Union, failed hopes of the leftist wings in the West, and Schadenfreude of the right wing circles of public opinion. This historical factor helps us to explain the diversity of reactions among the European Union countries to Russia's efforts aimed at regaining the status of a superpower. Not only the course of historical events, but also the way they are remembered determine the proportion of fear to hope in the current perception of Russian policy. If we do not bear this in mind, a lot of reactions to the presence of Russian capital or Russian science in Europe will seem paranoid.

Secondly, the economic potential of Russia has considerably increased over the past decade and the times when Russia's GDP was just a bit higher than the GDP of small Netherlands belong to the past. As early as in 2008, Russia was the world's eighth largest economy, ahead of Italy, Spain and Brazil, only behind such countries as the USA, China, Japan, Germany, India, Great Britain and France. ${ }^{1}$ In 2010, it held the sixth position in the ranking of the world's economies sorted by their GDP. The list was based

\footnotetext{
1 According to the Russian method of calculating GDP, Russia held the eighth place in 2005 and took the sixth position in 2007.
} 
on the estimates made by CIA, using the data provided by numerous organizations which monitor economic growth. The ranking indicates that the European Union is slightly ahead of the USA, but if we take each country separately, the list is as follows: ${ }^{2}$

$\begin{array}{rlrl}1 & \text { USA } & \$ 14,720,000,000,000 & 2010 \text { est. } \\ 2 & \text { China } & \$ 9,854,000,000,000 & 2010 \text { est. } \\ 3 & \text { Japan } & \$ 4,338,000,000,000 & 2010 \text { est. } \\ 4 & \text { India } & \$ 4,046,000,000,000 & 2010 \text { est. } \\ 5 & \text { Germany } & \$ 2,951,000,000,000 & 2010 \text { est. } \\ 6 & \text { Russia } & \$ 2,229,000,000,000 & 2010 \text { est. } \\ 7 & \text { Brazil } & \$ 2,194,000,000,000 & 2010 \text { est. } \\ 8 & \text { Great Britain } & \$ 2,189,000,000,000 & 2010 \text { est. } \\ 9 & \text { France } & \$ 2,160,000,000,000 & 2010 \text { est. } \\ 10 & \text { Italy } & \$ 1,782,000,000,000 & 2010 \text { est. }\end{array}$

Thirdly, there is a dark side to this success - such high GDP growth rate is a credit to the exploitation of resources, especially energy minerals, such as crude oil, natural gas and coal. Other industries in Russia are still not dynamic and competitive enough. The output of the fuel and energy complex (FEC) accounts for 30\% of Russia's GDP. The complex also provides over $40 \%$ of the country's tax revenue and over $67 \%$ of the export volume. However, it is the service sector that represents over half of GDP. ${ }^{3}$ The Economic Section of the Polish Embassy in Moscow produced a note, in which it estimated that "the fivefold growth of Russia's total GDP at purchasing power parity in the years 2003-2008 was influenced by real growth in just $21.6 \%$. 66.9\% of this growth was a result of a rapid price increase in the Russian market, and $11.5 \%$ can be contributed to the appreciation of the rouble against the U.S. dollar." 4 Hence, a high position on the list does not necessarily reflect the real strength of the Russian economy, especially in the light of recent self-critical statements of the

\footnotetext{
2 The World Factbook 2010, www.cia.gov.

3 Dokład ministra energietiki RF Sergieja I.Szmatko na prawitielstwiennom czasie w Gosudarstwiennoj Dumie FS RF 8 diekabria 2010 goda: 13, www.minenergo.gov.ru.

4 J. Rutkowski, Kryzys gospodarczy a miejsce Rosji w świecie. Produkt krajowy brutto Rosji na tle porównań międzynarodowych, Moscow, March 25, 2009, p. 3.
} 
Russian leaders, who are preparing another modernization plan for their country. ${ }^{5}$

Fourthly, among the factors that are fundamental to the cooperation and rivalry between Russia and the European Union in the field of energy are: the size of natural resources both sides possess, their dynamics (are they growing or shrinking, and at what pace), their physical accessibility and economic viability of their exploitation, the degree of their conversion, and - last but not least - political elites' strategic capabilities as regards taking advantage of such resources in international resources.

Russia has enormous natural resources - it had the highest crude oil production in the world in 2010. It was the first year in which Russia outperformed Saudi Arabia in this respect. ${ }^{6}$ Russia is also the world's biggest producer of natural gas and one of the largest coal producers. It has a dominant position in the world coal market: it is the second richest country in resources, it is the $5^{\text {th }}$ biggest producer and the $3^{\text {rd }}$ largest exporter. The Minister of Energy S.I. Szmatko is also planning to increase transmission capacity so that Russia can increase its coal exports to 140 million tons by 2010.7 Russian coal is cheaper than that form Australia even for Asian consumers. Coal resources are the most important source of electrical energy in the world (it obviously refers to Russia and the European Union as well), but the Asian region accounts for only $30 \%$ of the global turnover of coal as the main markets are located in Asia. Russia has $12 \%$ share of the world's trade of crude oil, four fifths of exports go to

5 For example, the article "Rossija wpieriod!" written by President Medvedev, which opened the debate over the need and potential for modernization. At present, the level of innovation and competitiveness in the Russian economy is very low not only according to European standards.

6 Russia is the $2^{\text {nd }}$ biggest consumer and the $6^{\text {th }}$ largest exporter of crude oil in the world. It holds the $5^{\text {th }}$ position on the world list of countries by production and consumption of electrical energy. In 2010, Russia extracted over 10 million barrels of crude oil daily which was the result comparable to the highest levels of extraction in the times of the Soviet Arabia. Saudi Arabia extracted 8.25 million barrels a day in 2010 .

7 The biggest consumers of Russian coal include the United Kingdom, Japan, South Korea and Scandinavia. 
Europe and Russia's total share in the European markets is estimated at $30 \% .8$

Dynamics of resources, as measured by the growth of new resources and investing in their exploitation, is not as high as expected by the present and would-be consumers of Russian enterprises from the fuel and energy complex. Reserves are becoming less accessible as they are located deep in the ground or under the surface of the sea, in very cold climate, in the areas devoid of transport and public utilities infrastructure, which is indispensable for carrying out such projects.

If the natural wealth of Russia is also to serve the development of other European nations, large-scale foreign investment is absolutely necessary. The present level of foreign investment in Russia is far from impressive: its total volume amounts to $\$ 266$ billion (figures from March 2010), which puts Russia in the $19^{\text {th }}$ position in the world. The list of leading investors is also quite odd as it includes countries such as Luxembourg, Cyprus or the Virgin Islands, along with Germany, the United Kingdom or the Netherlands. In 2005, for example, Luxembourg invested \$ 13.8 billion, companies from Cyprus invested $\$ 5$ billion, whereas the volume of German investment in Russia was only $\$ 3$ billion. It is commonly believed that such investment from tax havens is seemingly foreign, but in fact it is money from Russia and other post-Soviet countries invested back in Russia after being laundered abroad.

The cost of energy investment is even higher, and Russian enterprises do not have sufficient capital to finance huge energy projects on their own. Gazprom, despite its superior profitability and enormous assets, is the most heavily indebted company in the country. However, it still has high credit rating. In 2010, the top 100 Russian enterprises owed over \$ 283 billion to banks. Top positions in the latest ranking 100 biggest debtors published by Finans business magazine are occupied by companies from oil industry. Their total debt exceeded \$ 97 billion in the middle of the year... "Among the most indebted enterprises are state giants, such as

${ }^{8}$ Dokład ministra energietiki, op. cit. and Strategia energetyczna Rosji, quoted in Polish on the website of the Polish Embassy in Moscow. It will be quoted later as Strategia FR 2030 with the pagination as printed from the Embassy website. 
Gazprom ( $\$ 43.3$ billion - a 16\% decrease in 2010), Rosneft ( $\$ 28$ billion a 3\% decrease) and Transneft (\$24 billion - a 2\% increase). The first private enterprise - Oleg Deripaska's UC Rusal - holds the fourth place with $\$ 12.5$ billion debt. The following positions are occupied by Russian Railways, Lukoil, the aerospace holding company Oboronprom, and Roman Abramovich's metallurgical concern Evraz. The debt of Petropavlovsk steelworks grew by $311 \%$, which was the highest increase among the companies from the list." 9

Another important determinant of Russian strategies and behaviours is the issue of ownership and control of energy resources - are they state or privately owned and do public and private entities pursue similar policies in great strategic games? The fuel and energy complex encompasses both state and private enterprises, but most resources are in the hands of state companies and those private ones which are Russian (or with predominant stake of Russian capital) and have owners who do not come into conflict with the central political elite gathered around the duo of leaders. This tendency is well illustrated by the decision made by the Federal Agency for Exploitation of Mineral Resources, which at the beginning of December 2010 granted the right to develop Triebs and Titov mineral reserves in western Siberia. It is one of the biggest deposits of this kind in the world and the largest one in Russia as it contains almost a quarter of all crude oil resources in the country. ${ }^{10}$

What is less typical of Russian policy towards resource control is the privatization of state enterprises. In November 2010, the Russian government adopted a privatization strategy for the years 2011-2013. Among huge Russian concerns which are going into private hands is Rosneft, an oil company established in 2013.11 - This is the beginning of a new wave of selling the state wealth - Elvira Nabiullina, the Deputy Minister of

\footnotetext{
9 The Internet edition of "Rzeczpospolita", December 9, 2010, www.rp.pl.

10 B. Meyer, Basznieft zwycięzca przetargu na syberyjskie megazłoża ropy, December 3, 2010, www.energianews.pl.

11 The data presented by Ekspert magazine show that in 2008 Rosneft was the third largest enterprise by revenue in the Russian Federation. Its total sales were over 1 trillion roubles (approximately $\$ 30$ billion) with a net profit of 143.1 billion roubles (over $\$ 4$ billion). It was classified on the $158^{\text {th }}$ position of the Fortune Global 500.
} 
Economic Development told reporters. It is forecast that the Russian budget will gain 1 trillion roubles (about $\$ 30$ billion) from privatization. ${ }^{12}$ Within the next three years, however, the Russian government will not give up its control over any enterprises that are to be partly privatized. The only exception is Rosneft, but the state wants to keep the majority stake in this company.

The Kremlin's strategists believe that Russia must put the main emphasis on investing in foreign energy resources. In the summer of 2010, the oil concern Rosatom started building a uranium enrichment plant in the United States and it acquired 51\% of shares in the Canadian company Uranium One, which controls uranium deposits in Canada, the USA, Kazakhstan, the RSA, and Australia. ${ }^{13}$ In 2009, the federal budget has pumped \$ 1.6 billion into this project, which stresses its significance for the Russian government. In return, Rosatom offered a stake in its uranium resources in Kazakhstan and \$ 610 million. Uranium One is expected to become a foothold for further expansion of Russian business in the American continent.

Russians control about $12 \%$ of uranium production, $40 \%$ of the global uranium enrichment market and $17 \%$ of the market of production of fuel for nuclear plants. They sell fuel to over 74 reactors in 15 countries and are negotiating contracts for supplying another 20. They hold talks with the USA on the construction of a uranium enrichment plant in the United States. It would be a resource base for two new U.S. nuclear power plants. At present, the USA has 104 reactors, which produce one fifth of the energy in the whole country. ${ }^{14}$

The fuel and energy complex is the apple of the eye of the Russian political leaders (it was no accident that President Medvedev was the head of Gazprom for quite some time, the position he gained thanks to then President Putin). Foreign operations of state and private enterprises are

12 www.rp.pl, quoted from RIA Novosti agency.

13 Russia is the world's fifth largest producer of uranium, which forms the basis of nuclear power. It was not until November 2010 that the United States approved this transaction following a long debate and despite objections raised by a number of politicians.

14 Based on data from www.osw.waw.pl. 
coordinated by the Prime Minister, his Deputy, the Minister of Energy and the Minister of Economic Development. Regardless of economic waste and corruption prevalent in great energy concerns (which is reflected not only in media reports, but also in the notes of American diplomats revealed on the WikiLeaks site), their activities are cohesive and consistent enough to effectively develop large gas pipeline investment projects, such as the Baltic Nord Stream pipeline or the South Stream pipeline from the Caspian Sea to Austria, the WSTO (Wostocznaja Siberia Tichyj Okiean) crude oil pipeline leading from Western Siberia to the Pacific coast of China ${ }^{15}$ and to prepare new gas and oil fields for exploitation.

The evolution of the Russian energy strategy over the past few years is partly the expression of autonomous Russian interests, and partly the result of dialogue and cooperation with the European Union. Modernization concepts of the effective use of energy, developing renewable energy sources, imposing stricter ecological discipline on energy investment projects are pursued both in the European Union and the Russian policies, which may imply that the two sides have defined the areas of common or similar ground. Observations of the European dialogue on energy issues show that these areas include the following quite widely discussed problems:

1. Global challenges resulting from the increasing demand for energy in Asia, especially in China and India, and from the intensification of global rivalry for the access to energy carriers with the USA maintaining its dominant position in this sector of the global system.

2. The need for harmonizing environmental and energy objectives in integrated strategies of national and international security.

3. The need for extending the time horizon for the strategy of socioeconomic development and its synchronization with the potential of all forms of the production, distribution and consumption of energy.

15 One of the minority shareholders of Transneft, which has invested in the WSTO project, accused the company's directors of the embezzlement of \$ 4 billion during the construction of the first leg of the crude oil pipeline to China, which was launched at the beginning of 2011. 
4. The need for enhancing the role of new energy resources in the energy mix, especially renewable energy sources and the ones that are environment friendly and safer for people's health.

5. The need for improving clean coal technologies, such as coal gasification, underground combustion.

The new Energy Strategy of Russia for the Period until 2030, which is a time horizon ten times longer than in the previous strategy, ${ }^{16}$ was adopted by the Russian government on August 27, 2009. Thanks to this strategy Russia has ascended to the new level of the battle for the future of economies and international influence. The objective of the Energy Strategy for 2020 was to influence the world prices of energy carriers through conducting dialogue with producer and consumer countries. The Strategy for 2030 stipulates that Russia will not only influence the world prices, but will also control international transport infrastructure.

Among the main problems in the field of "foreign energy policy" are the following: ${ }^{17}$

- reduction in demand and cut in prices for energy resources due to the world economic crisis;

- insufficient diversification of sale markets for Russian energy resources and of export commodities structure;

- preservation of the Russian export dependence on transit countries;

- politicization in energy relationships between Russia and foreign countries;

- low level of Russian energy companies activity at foreign markets.

The last four problems are all structural and they clearly show the areas of the permanent conflict of interest between Russia and Europe, including ten new European Union member states from this region, because:

16 I presented the strategy adopted in 2003 in my article in European Studies No. XV Z 2006, published in Gdynia.

17 Strategy FR 2030, op. cit., p. 12. 
- Diversification of sale markets means more exports to Asia and even the USA, and fewer exports to Europe (the WSTO pipeline).

- Russia's independence from transit countries is actually equivalent to its independence from Ukraine, Belarus, Poland, the Baltic countries, the Czech Republic, Slovakia, Hungary, Bulgaria, and Romania. This goal is to be achieved thanks to new distribution grids, such as Nord Stream, South Stream, the Burgas-Alexandroupoli pipeline. The strategic document from 2003 in chapter VI stated directly that Russian gas industry should "secure political interests of Russia in Europe," which resulted in the recommendation that gas and oil transport should omit Russia's neighbouring countries and transit costs should be minimized. Thus, the pipeline under the Baltic will connect Russia with Western Europe via Germany, bypassing Poland.

- Russia will probably avoid "politicization in energy relationships" through diplomatic denial that "foreign energy policy" - as named in Strategy 2030 - does not have a lot in common with the political goals of Russia and is determined by purely economic interests of oil and gas companies. However, Strategy 2030 stipulates that the primary task of such foreign policy is "consideration of Russia's national interests in the context of the developing system of world energy markets operation." The strategy promises stability and predictability of world markets if Russia's national interests are taken into account.

- New globalist ideas of the establishment of Russian energy transnational concerns and organizing energy transport streams between Europe and Asia.

Moreover, Strategy 2030 also puts emphasis on the coordination of its energy strategy with prospective plans and energy strategies of other market players, including the European Union. ${ }^{18}$

18 M. Gołębiewska, Ratunek dla flagowego okrętu: strategia energetyczna Rosji do 2030 roku, The Energy Studies Institute, www.wnp.pl, accessed on January 10, 2011. 
On December 13, 2010, at the session of the Security Council of the Russian Federation, Dmitry Medvedev instructed the government to draft an Energy Security Doctrine. The President said that "energy security in any state is a guarantee of the nation's sovereign development." ${ }^{19}$ Priority measures to implement the doctrine should include "sustainable long-term uninterrupted supply of energy resources, active development of hydroelectricity and alternative energy sources, setting rapid reaction procedures for emergency situations, modernizing fuel and energy sector enterprises, ${ }^{20}$ special efforts to protect energy facilities from terrorists, and international energy cooperation."

On December 9, 2010 in Moscow, the leaders of Russia, Kazakhstan and Belarus have adopted a Declaration on the establishment of a Single Economic Area between the three countries and the agreements which regulate its principles. The SEA will begin functioning on January 1, 2012, and will lead to the establishment of a common market by 2015 through the application of four freedoms - concerning the flow of goods, services, capital, and labour force - following the example of the European Communities, the Single Economic Area is another stage in the process of integration of Russia, Kazakhstan and Belarus, which formed a customs union on July 1, 2010. The initial draft of the SEA was prepared as early as in 2003 and was to be developed with the participation of Ukraine, which, however, did not ratify the agreement. This, in turn, led to the crisis in the work on the project. By establishing the SEA, Russia is trying to adapt to the general regional tendency towards integration through free trade zones or customs unions and prevents further weakening its links with Belarus and Kazakhstan. "In the years 2000-2008, the share of exports of Kazakhstan and Belarus to the Russian Federation in the total export volume of these countries decreased, respectively, by $11 \%$ (to 9\%) and by $18 \%$ (to $32 \%$ )." 21

19 The official website of the President of Russia, http://state.kremlin.ru/face/9809, www.kremlin.ru, accessed on December 13, 2010.

20 That is why the President mentioned smart grids.

21 I. Wiśniewska, A. Jarosiewicz, K. Kłysiński, Wspólna Przestrzeń Gospodarcza: kolejny etap integracji wokół Rosji, www.osw.waw.pl, accessed on December 15, 2010. 


\section{THE OFFENSIVE AND EXPANSIVE NATURE OF RUSSIAN POLICY: OPERATIONAL GOALS AND PRACTICAL METHODS}

Experts on Russia and its history commonly believe that its energy strategy is offensive and expansive, being a new form of superpower policy rather than a business activity. This strategic objective becomes clear when we forget the officially declared policy and consider Russia's real goals towards the countries of Central and Eastern Europe. In the following part of this text, we present the summary of the objectives of the great national strategy ${ }^{22}$ not just the energy strategy, which is the result of the analysis of numerous official documents and actual Russian policy after 1990. Operational goals offer real guidelines for practical activities, unlike the aims declared in strategic documents.

The operational goals of Russia's grand strategy towards the countries of Central Europe, including the European Union's new member states, are as follows:

1. Restoring Russia's political and diplomatic influence in this region, ${ }^{23}$ which would counterbalance the entry of the USA and NATO into the former sphere of Russian domination.

2. Minimization of economic, political, and cultural involvement of Western and Central European countries in Ukraine, Belarus, Moldova and the Caucasus, and reducing the cooperation of these countries with NATO members.

3. The establishment of a customary sphere of influence with the formal or informal right to veto against some forms of Western presence in this region, e.g. missile defence, enlargement of NATO.

\footnotetext{
22 It is also often referred to as the grand strategy.

${ }^{23}$ For the purpose of this analysis, I use the term "the region of the European Union's new member states" to refer to the countries which became EU members after the collapse of the Soviet Union. They used to be in the sphere of Russian dominance and after liberating themselves from this dependence they entered the structures of the transatlantic community.
} 
4. Reducing the criticism of Russian internal and foreign policy expressed by political journalists and politicians from this region.

5. Increasing the role of pro-Russian circles in the European Union and NATO. They would counteract negative opinions on Russian activity, expressed by the countries which are traditionally critical of Russia, such as Poland, Lithuania and Estonia.

6. Obstructing any initiatives which aim at Poland's accession to G-20, although its GDP stood at the $19^{\text {th }}$ position in the world.

7. Direct contacts with the leaders of pro-Russian countries of Western Europe in order to marginalize the Central and Eastern European countries.

Russia pursues these objectives with different intensity for different European Union's new countries from Central Europe and the Balkans as they differ in many ways, for example, geostrategic potential, traditions of cooperation with Russia, approaches of elites governing them, and their memory of failures and successes in their past relations with Russia.

The abovementioned region presently includes 10 countries and will soon be enlarged thanks to the accession of Croatia and Serbia. The countries in the region are grouped according to different typology criteria: their presence in the state structures of the Soviet Union and their present integration links maintained after joining the European Union and NATO. Thus, the region includes the countries which used to be the members of the Soviet Union (Estonia, Lithuania, Latvia, i.e. so called Baltic group) and those which have never been a part of it (the other seven countries). The latter group may be divided into two groups:

- The Visegrad Group (V4), which includes the Czech Republic, Poland, Slovakia and Hungary, with Catholic and Protestant traditions.

- The Balkan Group, which includes Bulgaria and Romania with Orthodox Church traditions and Slovenia with Catholic traditions.

Russia uses strategic game methods towards this region, just like the ones it has been using with regard to close neighbours of the Russian 
Federation, such as Ukraine, Belarus and the Caucasian republics. Thanks to this it may use energy resources to achieve its political goals. ${ }^{24}$

Russian strategic game methods in the field of energy and the use of energy carriers, such as natural gas, crude oil and coal, are quite diverse. The list presented below is probably not complete, but it is sufficient to justify the statement that Russia pursues an offensive strategy towards 10 new members from the ABB area (the Adriatic Sea, the Baltic Sea and the Black Sea) ${ }^{25}$ in order to:

1. acquire potentially rich reserves and prospecting licences outside the Russian territory to exploit them later (upstream activities);

2. buy energy carriers cheaply in Central Asia and sell at a twice higher price in, for example, Georgia;

3. deprive foreign companies of prospecting licences which they have legally acquired and make them leave Russia;

4. sell as many energy resources as possible at the highest possible price to reliable consumers, who are capable of paying market prices for them (downstream operations), and to maximize sales of highly processed forms of energy, such as petrol and diesel fuel instead of crude oil, and LNG instead of natural gas;

5. own and/or control distribution grids of crude oil, natural gas, coal and electrical power so as to specify who and on what conditions will have access to them - it shows lack of respect for the principle of equal access for third parties;

6. avoid legal forms of international commitments, which limit the freedom of independent action that Russia may take without the need for compromise or serious concessions in favour of other players in the field of energy or in the broader area of the game for international security, e.g. a refusal to ratify the European Energy Charter;

7. cut off energy supplies to partners who are difficult in negotiations for price and delivery terms;

24 The article does not focus on the analysis of methods and tools applied in other, non-energy areas of the grand strategy implementation, but we may point out the tendency for harmonization of Russia's activities in different fields.

25 We will call this group ABB10 further on in the article. 
8. include clauses which forbid reselling energy surpluses in longterm contracts;

shut down the crude oil or gas pipelines which supply competitors, e.g. Lithuanian Mažeikiai after it was taken over by the Polish PKN Orlen; ${ }^{26}$

9. bypass transit countries which are critical of Russia and/or have unstable political systems, such as, for example, Ukraine, Belarus and Poland bypassed by Nord Stream or conflicts with Bulgaria concerning South Stream;

10. charge different prices from different customers - from full market prices (for most EU countries), through fixed prices specified in long-term contracts (which may be even higher than current market prices ${ }^{27}$ ), to reduced prices (much lower than market prices) for selected consumers (sometimes they are the same former Soviet Union republics which Russians view as unreliable transit countries). Russians once again gave in to Belarus at the end of 2010, when they agreed to sell crude oil to Belarus at a lower price in 2011. Thanks to this the Belorussian government will save $\$ 4$ billion. In response to raising transit feed by Minsk, Russia suspended supplies at the beginning of 2011. The spot price of Urals oil sold by Russia in Rotterdam Europort is about $\$ 696$ per ton, whereas Belarus will pay about $\$ 360$ per ton. In turn, the Baltic states will be charged the highest price, as they have to pay more than Western Europe countries.

26 Gas supply suspension is a method used not only by Russian producers and the Russian monopoly owner of crude oil distribution grids, Rosneft. On January 1, 2011, the Ukrainian Naftogaz suspended supplies to Poland via Hrubieszów, citing the new Ukrainian law, which stipulates that all natural gas extracted in Ukraine has to be consumed in this country and cannot be exported. Poland had to face such a delivery cut for the same reasons at the beginning of September 2010. www.naftagaz.pl, accessed on January 13, 2011

27 For example, at the beginning of 2011, Poland had to pay prices higher than the market ones, as specified in the long-term contract. 


\section{THE BASIS AND FRAMEWORK FOR COOPERATION BETWEEN THE EUROPEAN UNION AND RUSSIA}

The shock effect of turning off the gas tap to Ukraine became an impulse for the reorientation of strategic thinking in the European Union. It resulted in the new premises of strategic thinking within the Union and the ABB10 group:

1. The recognition that Russia may continue its expansion in the international arena not only in its close neighbourhood (the Commonwealth of Independent States), but also in Central Europe and the Balkans (former sphere of Soviet dominance) and in the whole Europe.

2. Understanding that energy security is common and even more indivisible in the world of growing interdependencies and internationalization of all relations than it used to be.

3. Understanding that the European Union has to respond jointly to the risk of Russian expansiveness and offensiveness and that this response has to be constructive and prospective rather than a defensive or passive reaction or forced adaptation to threats.

Russia and the European Union, including ten new countries from the $\mathrm{ABB} 10$ group, must and want to cooperate in the field of energy security as they are mutually dependent.

- The European Union is an energy importer and it is going to be even more dependent on imports of crude oil and natural gas in the future, until the Union reaches its target of sourcing 20-25\% of their energy needs from renewables, which will not happen soon, or until we master a technology of energy generation from thorium, ${ }^{28}$ which has a lot bigger energy potential than uranium and plutonium currently used in nuclear power plants. If this trend continues, Europe will become more and more dependent on

28 M.S. Kazimi, Thorium Fuel for Nuclear Energy, American Scientist (September-October 2003), Uranium 2007: Resources, Production and Demand, Nuclear Energy Agency (June 2008). At present, political and strategic interests stand in the way of the development of thorium-based technology. Thorium is a lot safer and more efficient source of energy than uranium and it is about six times more plentiful than uranium. 
imports of hydrocarbons - in 2006, the whole EU's dependence was $50 \%$, and it is forecast to increase to $70 \%$ by 2030 . With respect to natural gas, the dependence on imports will grow from $57 \%$ to $84 \%$, and as regards crude oil, it will rise from $81 \%$ to $93 \% .{ }^{29}$

- Russia is a great exporter of energy carriers and its prosperity is primarily determined by the success of these exports. The European Union's markets account for four fifths of Russia's energy exports, generating huge revenues for Russia, without which it would not be in the top six countries of the world by GDP. The Russian elite is well aware of this fact and it considers it to be a serious threat to Russia's independence from the European Union. Therefore, it is making efforts towards modernization in order to increase the role of non-resource exports. ${ }^{30}$

- In October 2000, the EU and Russia agreed to start an Energy Dialogue, ${ }^{31}$ and since 2006 - following a shock after turning off the gas tap to Ukraine - the Union has been making efforts to formulate a cohesive and joint energy policy. On May 5, 2010, the European Parliament's President Jerzy Buzek and the European Commission's ex-president opened discussion on new EU Energy Community, which would link the European Union with other European countries. ${ }^{32}$ In June 2010, following Germany's example, the whole European Union and Russia launched partnership for

29 www.Eurostat.eu, data on energy imports.

30 Apart from energy carriers, Russia also exports large amounts of grain. It was the world's third biggest grain exporter in 2009.

31 Joint Report EU-Russia Energy Dialogue 2000-2010: Opportunities for Our Future Energy Partnership, (Brussels/Moscow, November 2010).

32 European Parliament resolution of 25 November 2010 on Towards a new Energy Strategy for Europe 2011-2020 is an important step towards the European Energy Community, just like exercising the principle of TPA (Third Party Access) as well as a resolution on EPSTE, concerning investment in low-emission technologies. EU's Third Energy Package which entered into force on March 3, 2011, is another step towards the common energy market in Europe. 
modernization, the key part of which is cooperation in the field of energy security.33

- Despite Russian efforts towards diversification of exports (by enhancing the role of Asia in the overall structure of energy exports) and the Union's attempts to diversify energy imports (by enhancing the role of supplies from the Middle East and the Caucasus through launching the Nabucco pipeline project and the existing pipelines: the Interconnection Turkey Greece Italy (ITGI) and the Trans Adriatic Pipeline), Russia and the European Union, especially the countries of the ABB10 group, will long remain mutually dependent, regardless of national interests and specific perceptions of accompanying threats. ${ }^{34}$

- The strategic weakness of the European Union is reflected in the following facts:

1. Lack of joint policy which would guard the Union's common interests.

2. Lack of mechanisms for quick consultation and coordination of national energy policies and mechanisms for mutual support in emergency cases.

3. The Energy Community is still just an idea rather than a PanEuropean community of energy networks, an internal energy market or a system of principles adopted in the whole continent. Enlargement of the Treaty of the Energy Community, stipulated in the EU's Strategy 2020, would help to coordinate the policy towards third party countries, especially the key ones such as Russia.

33 13th Session of the Russia-EU Parliamentary Cooperation Committee, 15-16 December 2010, Strasbourg. The $25^{\text {th }}$ EU - Russia Summit took place in Rostov-on-Don on 31 May and 1 June. At the summit, the new Partnership for Modernization was officially launched. Its aim is to offset the project presented by Poland and Sweden, which was inaugurated as the Eastern Partnership in 2009 and initially did not include Russia.

${ }^{34}$ It is quite a common view that Europe's role in Russian foreign policy will diminish in future and there are strong arguments to support this thesis. See: Th. Gomart, Europe In Russian Foreign Policy: Important but No Longer Pivotal, IFRI Russia/NIS Center, "Russie.Nei Visions" 2010, No. 50. 
4. Many experts believe that the ambitious $3 \times 20$ goals included in the Europe 2020 Strategy are unrealistic and will not be achieved. $3 \times 20$ are the Union's official goals: to reduce greenhouse gas emissions by $20 \%$ compared to 1990 levels, $20 \%$ of total energy consumption to be from renewable energy and increasing energy efficiency by $20 \%$. The countries of the $\mathrm{ABB} 10$ group, because of their lower level of development and lack of investment funds, may be a serious obtrusive factor in the process towards the accomplishment of these ambitious targets, which is supposed to decrease the Union's dependence on Russian energy carriers.

5. Conflicts of interest among EU countries were once again reflected in hot debates over the EU climate and energy package as well as in strong opposition of energy ministers of the biggest EU countries (including Germany, France, the United Kingdom and the Netherlands) against financing energy projects from the EU budget. Despite postulates from smaller and poorer EU countries (such as Slovakia, Lithuania, Estonia, Malta, Cyprus, Portugal, and Ireland), this idea was rejected at the session of the Council of the European Union. Wealthy Union members claim that such investments should and can be financed by energy companies and banks with no subsidies from public funds.

Members of the European Union have significantly different interests and perceptions towards Russia. Therefore, we need a typology of strategic orientations towards Russia which exist in the European Union. Young Italian scholars Stefano Braghiroli and Caterina Carta distinguished the following four types of the EU member states according to their attitude towards Russia:

1. "Eastern divorced," who are usually unfriendly or have cold attitude towards Kremlin - the Czech Republic, Slovakia, Poland, Lithuania, Latvia and Estonia. A good example of a revindication policy is the statement of the Lithuanian President Valdas Adamkus who, on January 3, 2008, demanded that Russia should pay \$ 28 billion as a "compensation for the Soviet occupation," quoting 
experts who calculated that Russia should pay over $\$ 5$ trillion to those under its occupation - e.g. Poland, Ukraine, Germany, Moldova. President Adamkus suggested that it could be paid in the form of Lithuania's share in oil and gas reserves in Russia. ${ }^{35}$

2. "Vigilant Critics" - Romania, Slovenia, Bulgaria, Hungary, Sweden and the United Kingdom.

3. "Acquiescent Partners" - Belgium, Denmark, Finland, France, Germany, Ireland, Luxembourg, the Netherlands, Portugal and Spain.

4. "Loyal Wives" - they maintain very good relations with Russia and actively support its initiatives, including the ones concerning energy; this group includes Greece, Italy and Austria. ${ }^{36}$ In order to systematically depict different countries' attitudes towards Russia, an index of "Russian friendliness" has been built. ${ }^{37}$

Most countries of the ABB10 group are either Eastern Divorced or Vigilant Critics of Russian policy. Therefore, it is not surprising that the Russian political elite is more successful in building distribution grids in cooperation with Bulgaria and Slovenia from the ABB10 group or with Germany, Austria, Italy and Greece than with such countries as Poland, the Czech Republic, Slovakia or the Baltic states.

\section{A PARTICULAR POSITION AND STRATEGY TYPES OF THE EU'S NEW MEMBER STATES IN THE ENERGY GAME BETWEEN RUSSIA AND THE EUROPEAN UNION}

The countries of ABB10 have a few common characteristics which describe their energy situation:

\footnotetext{
35 www.bbc.news, accessed on December 12, 2010.

36 S. Braghiroli, C. Carta, An Index of Friendliness toward Russia: An Analysis of the Member States and Members of the European Parliament's Positions, September 15, 2009, Electronic Publications of Pan-European Institute, www.tse.fi/pei.

37 Braghiroli, Carta, op.cit., p. 12. The index has been built after analysing votes of the members of the European Parliament from different countries on the issues concerning Russia.
} 
- high level of dependence on imports of energy carriers, especially on imports from one country - Russia. They differ in their lack of energy autonomy, which fluctuates from $20 \%$ to $100 \%$ of these nations' dependence on imports, but this level is usually higher than in the North-West countries of the European Union Gazprom supplies almost two thirds of the natural gas imported to Central Europe and only 25\% of the gas imported to the European Union as a whole;

- high investment needs in the fuel and energy sector with limited own financial potential in relation with EU climate packages;

- the need for joint efforts of the whole Union and for loyal cooperation of the EU's new member states from the ABB10 group (the Visegrad Group V4, bilateral agreements in this region, e.g. Poland-Lithuania, Poland-the Czech Republic, threats resulting from very close German-Russian cooperation, e.g. Nord Stream for the new countries);

- the need for diversification of energy sources as the foundation of energy security for the whole region and for each country separately;

- avoiding financial losses resulting from supply reduction by Russia and/or Ukraine. These losses are quite significant: some experts claim that the gas crisis of January 2009 cost the affected countries about 800-900 million euro. ${ }^{38}$

How do the countries from the ABB group tackle the strategic challenges in the field of energy and how do they react to the steps Russia takes? Most of them try to follow a few simple rules:

1. Avoiding the situations in which one energy carrier (e.g. natural gas or crude oil) is supplied by a single country (avoiding a trap of the monopoly supplier).

2. Avoiding dependence on one distribution grid and one direction of energy flow, for example from east to west (a trap of the monopoly distribution grid).

38 M. Melcak, Enhancing Europe's energy security through greater use of liquefied natural gas, Report to Parliamentary Assembly, December 22, 2010, Doc.12424. 
3. Avoiding intermediaries in energy transactions: companies imposed by Russian oil companies, especially by Gazprom and its subsidiaries, the purpose of which is to privatize profits, to put it mildly. Companies such as Livela ${ }^{39}$ or RosUkrEnergo are obligatory intermediaries, against which some countries defend themselves quite effectively. ${ }^{40} 80 \%$ of the Russian gas is supplied to Western consumers, including the ABB10 group, via Ukraine, and the mediation of RosUkrEnergo means billion-dollar profits.

Before we move on to analysing the relations of particular ABB10 countries with Russia, we must note that this analysis is partly based on the typology of national strategies of the ABB10 countries towards Russia which was proposed by Ryan Miller in 2008 and is based on empirical research. Ryan Miller examined approaches of "strategic players" like Poland and Romania, and "commercial opportunists" like Hungary and Bulgaria. ${ }^{41}$

Deeper analysis of the nuances of the negotiation games Romania and Bulgaria play with regard to the Nabucco and South Stream pipelines leads us to the following, more subtle view: there is actually no difference between commercial opportunists and strategic players as both Balkan countries take a stand of one or the other alternately. They just want to maximize their benefits both from the cooperation with the European Union on the Nabucco issues and from the collaboration with Russia on the problems concerning the other pipeline. Two pipelines will be probably built, and Bulgaria and Romania will participate in both of them, accompanied by Hungary and Austria from outside the Balkans. The his-

\footnotetext{
39 Jak mała spółka pobiła rosyjskie koncerny, November 3, 2010, www.rp.pl, accessed on December 21, 2010.

40 The Hungarian subsidiary of RosUkrEnergo has lost the right to operate in Hungary.

41 R.R. Miller, Central Europe's Energy Security Schism, A publication by the Center for European Policy Analysis (CEPA), July 2008. However, the recent decisions made by "commercial opportunists" deny Miller's theses - the policies approved by socialist governments in Budapest and Sofia were later changed by the prime ministers of centre-right governments, which won the elections and reformulated their national strategies towards Russia.
} 
tory of the Nabucco and South Stream projects is a perfect illustration of the changing nature of energy policy in the Balkans. Initially, Nabucco was to be completed by 2012 and was going to be used for transmitting gas from the Caspian Sea region (Baku) via Turkey, Bulgaria, Romania and Hungary to Austria. The pipeline will be 3,300 km long and will transmit oil from the Caspian Sea countries (Azerbaijan, Turkmenistan) and Iraq via Turkey, the Black Sea, Bulgaria and Hungary to Austria. The project is being developed by the Nabucco Gas Pipeline International with the following shareholders: OMV (Austria), MOL (Hungary), Transgaz (Romania), Bulgargaz (Bulgaria), BOTAŞ (Turkey) and RWE (Germany). The construction will start in 2011 and the pipeline is expected to be operational by 2016 and it will carry 31 billion cubic meters of natural gas per year. The costs of the project are estimated at 9 billion euro. Although the pipeline needs about 31 billion tons to be filled, at the initial stage of operation supplies from Azerbaijan - at least 7 billion cubic meters - will have to do. It must be noted here that on January 13, 2011, the Azeri leader and the bosses of the State Oil Company of Azerbaijan (SOCAR) declared that the gas for Nabucco will flow from a new, giant Shah Deniz field, which is a great success of the EU's diplomacy. This declaration will perhaps save the project.

The competitive Russian South Stream is expected to be completed earlier. In response to the Nabucco design, in 2007 Russia launched the alternative South Stream project, backed by the Italian energy concern ENI and S. Berlusconi's government. South Stream will be built under the Baltic Sea, then via Bulgaria, Greece, Croatia, Italy and Hungary to Austria. What is important, it will have twice bigger transport capacity than Nabucco. Russians are critical of the Nabucco project, because until now they have had control over exports of Azeri and Turkmen gas. Not only are they afraid to lose this control, but they also fear the competition from Azeri and Turkmen supplies via the new pipeline.

The participation of Hungary is absolutely essential for both projects as it is a transit country on the way to Austria, and then other Western consumers. Hungarians are also dependent on Russian gas (77\%) and oil (97\%) imports, but Prime Minister Gyurcsany and his successor Orban drew other strategic conclusions from this fact. The former promised to 
cooperate with Russia in the construction of South Stream, although he did not reject the Nabucco project, either. ${ }^{42}$

Russians began to make efforts to gain influence on the Nabucco project a few years ago. The Hungarian oil and gas company MOL and one of its main shareholders Austrian concern OMV played a key role. Thus, Gazprom tried in vain to acquire a large chunk of MOL shares in 2007. Russians launched another takeover bid and in April 2009 Surgutneftegas bought $21.2 \%$ of MOL shares from OMV. They paid the Austrian company $\$ 1.4$ billion in cash. The transaction brought down a shower of criticism in Hungary as the two sides had not informed the company board about their negotiations. Russians had not presented their strategy or plans. Hence, Budapest regarded it as a hostile takeover. Despite owning 21\% of MOL shares, Surgutneftegas will not be included in the shareholders' register. It means it will have no influence on the company and will not be represented on its board. On November 18, 2010, the Hungarian Court of Appeal ruled that the refusal to enter Surgut in the shareholders' register of MOL was lawful.

Surgut is the richest oil company in Russia, with over 100 thousand employees. It produces almost 62 million tons of crude oil per year (compared to 1.9 million tons produced by MOL). It has about $\$ 20$ billion of ready cash, so it does not have to raise finance through debt. However, it has too few refineries in Russia, and that is why the acquisition of MOL was an opportunity to expand. The other shareholders of MOL (including the State Treasury $-7.1 \%$, the Czech company CEZ - 7.3\% and foreign investors $-25.8 \%$ ) demanded that Surgut disclosed its shareholders and company results in accordance with International Financial Reporting Standards as required by Hungarian law. Surgut refused. This publicly quoted concern does not reveal its ownership structure in Russia, either. Russian media believe that the chairman of the board Vladimir Bogdanov is the real owner. Officially, he holds $5 \%$ of shares but, together with a few partners, he actually controls over $60 \%$ of shares through 30 subsidiaries.

\footnotetext{
42 S. Woehrel, Russian Energy Policy Toward Neighboring Countries, Congressional Research Service, Report for Congress, September 2, 2009, p. 18, www.crs.gov.
} 
After the acquisition, Russians could not register in the court nor could they participate in managing MOL until the Hungarian Financial Supervisory Authority (HFSA) completed its audit. The HFSA was to discover whether OMV and Surgut had acted in accordance with the Hungarian Stock Exchange Law; especially with respect to a suspicion of insider trading. ${ }^{43}$

The Hungarian government is striving to repurchase its shares in MOL from Surgutneftegas despite lack of funds in the budget. Within the framework of the broader agreement with Russia, Hungary will regain its control over MOL, but in return it will get more involved in the development of the South Stream project. In January 2011, Russia and Hungary set up the company, jointly owned by Gazprom and the Hungarian Development Bank, which will be in charge of building the Hungarian leg of South Stream. On October 31, 2008, at the $2^{\text {nd }}$ Energy Forum held in Budapest, Prime Minister Orban, who was in the opposition, proposed that the Visegrad Group V4 should establish its joint energy policy in order to strengthen its position in negotiations with Russia. In February 2010, at the Energy Summit in Budapest, when Victor Orban was Hungarian Prime Minister again, 11 countries expressed their support for the Nabucco project and for linking LNG terminals in the countries lying on the Baltic Sea, the Adriatic Sea and the Black Sea, which would give new meaning to the ABB10 group. On July 20, 2010, at the Visegrad Group Summit in Budapest, the V4 countries confirmed their willingness to coordinate their energy policies within the group and the whole European Union, especially as regards the construction of distribution grids, diversification of supply sources and energy security. Thus, it is quite clear that Hungary supports the EU's policy towards reducing Russian supremacy and makes efforts to eliminate companies with unclear ownership structures from the market (e.g. the Hungarian Energy Office (MEH) has suspended the gas trading license of gas-trader Emfesz, which controls $20 \%$ of the gas market in this country). ${ }^{44}$

\footnotetext{
43 Sad obronił MOL przed Rosjanami, November 18, 2010, www.rp.pl.

44 Węgry: spótka Emfesz wypierana z rynku gazu, www.osw.waw.pl.
} 
The Bulgarian Energy Strategy by 2020 (formulated in June 2010) includes the biggest investment project in the history of Bulgaria - the construction of the nuclear power plant "Belene," although the country lacks necessary funds $-10-12$ billion euro. Bulgaria conducts quite an odd and opportunistic policy on the issue of distribution grids as it searches for profit opportunities in its cooperation both with Russia and with the European Union. On June 17, 2010, after the Bulgarian authorities had yet again expressed their criticism of their energy cooperation with Russia and the South Stream project, the head of Gazprom, Alexey Miller, suggested changing the route of the pipeline, which could lead through the territory of Romania. On October 13, 2010, the representatives of the Russian Gazprom and the National Gas Transmission Company Transgaz of Romania met in Bucharest to sign a Memorandum of Intent to prepare a feasibility study for the Romanian section of South Stream. The fact that Gazprom signalled its intention of cooperation with Romania, which had not been considered as a transit country before, may serve the purpose of exerting more pressure on Bulgaria which still delayed making a final decision on the issue of building the pipeline on its territory.

The parties of the memorandum agreed to form a joint expert group to perform the preliminary analysis of the technological and financial conditions of building the pipeline through the Romanian territory. However, they did not decide to establish a company that would prepare the feasibility study, which, together with intergovernmental agreements, is a standard procedure before making a decision on investment. It indicates the intentional nature of this document. Moreover, building the pipeline in Romania is difficult because of Ukraine's reluctance to approve the route through its territorial waters. The Russian-Romanian memorandum must be viewed in the context of another round of Russian-Bulgarian talks on gas, which were held in Sofia on October 15, 2010. The fact that Moscow began talks with Bucharest was to urge Bulgarians to sign agreements of the establishment of a company to be entrusted with the task of preparing the feasibility study for the Bulgarian leg of South Stream. This pressure seems to be bringing effects: immediately after the talks in Sofia the chairman of Gazprom, Aleksey 
Miller, announced that the company would be set up within a few weeks. ${ }^{45}$

At the Baku Energy Summit, held on November 13-14, 2008, which attracted presidents of Poland, Lithuania, Ukraine, Georgia and Turkey, prime ministers of Romania, Hungary and Estonia, the European Commissioner for Energy and the U.S. Secretary of Energy, Romania confirmed its support for the Nabucco project. However, the Romanian policy tends to be isolationistic: Romanians are not eager to get involved in huge projects as their financial resources are scarce and they cannot rely on financial backing from abroad.

The difficulties that Russia encounters in developing South Stream are also associated with growing energy independence of particular South European and Balkan countries (especially Bulgaria and Turkey), new dynamics of competitive projects (especially Nabucco and other grids in the EU South Corridor). Other weaknesses of South Stream also emerged, such as lack of definite support from the countries which are key to the project (mainly Bulgaria and Turkey), which results in delay in marking out the final route of the pipeline. South Stream would have to run on the bottom of the Black sea through the Ukrainian or Turkish special economic zone. While the current authorities in Kiev are against the South Stream project, which would harm Ukraine's interests regarding gas transit to Europe, Ankara's standpoint on this issue was not clear-cut for quite some time.

When discussing energy relations between the Czech Republic and Russia, balanced autonomy must be considered. Czech-Russian relations are treaty-based (almost 80 treaties) and institutional (there is a bilateral intergovernmental commission with 10 working groups, including one for military and technological issues and another for nuclear energy). ${ }^{46}$

Russia supplies three quarters of natural gas imported by the Czech Republic, and the Czech demand for oil is fulfilled in $60 \%$ by Russian supplies. The rest comes from Western Europe via the IKL pipeline. Poland's south neighbours make only partial use of this pipeline's distribution capac-

\footnotetext{
45 A. Łoskot-Strachota, Komplikacje wokó gazociagu South Stream, June 26, 2010, www.osw.waw.pl, Rosja naciska na Bułgarię w sprawie South Stream, October 20, 2010, www.osw.waw.pl.

46 Visegrad Countries and Russia, Visegrad.info, September 30, 2009.
} 
ity, which is 11.5 million tons a year (e.g. they only used 3 million tons in 2009). Although oil supplies from Western Europe via Germany would be sufficient to satisfy the needs of the Czech Republic, it is still buying Russian oil because of lower costs. Even if $100 \%$ of oil was supplied from the West, the capacity of the IKL pipeline would not be fully utilized.

In 2008, the Czech crude oil pipeline operator Mero AS signed a contract with the German company Deutsche Transalpine Oelleitung $\mathrm{GmbH}$, under which the Czech side may use the TAL pipeline in case oil supplies via the Druzhba pipeline are reduced or suspended. The contract was later prolonged to 2015. The Czech company also expressed interest in acquiring some shares in the pipeline. The TAL pipeline links Germany with Italian ports via Austria. Oil may be transmitted from Germany to Czech refineries through the IKL pipeline.

Thus, the Czech Republic does not fear a threat of supply suspension as it has an alternative source. The country aims at ensuring permanent surplus in energy production and it is a large electrical energy exporter. The electrical markets of the Czech Republic and Slovakia were reconnected in 2009.

The Czech economy, just like the Polish one, is based on fossil fuels, especially coal (Czechs still have 750 million tons of coal). This fuel guarantees a certain degree of independence from Russia, but conventional power plants are thirty years old, so many of them will be closed down within the next five-eight years.

Therefore, the Czech Republic give top priority to nuclear power (which now accounts for $20 \%$ of electrical energy), but fast departure from coal may not be possible. Having no seaside, Czechs cannot use wind power plants in the same way other countries do. They have to import gas, also from Russia, but the use of gas as fuel represents only $18 \%$ of total fuel consumption. This percentage is expected to rise to $21 \%$ by 2050 . Within the next few decades Czechs are planning to increase the share of nuclear power in the market from $15 \%$ in 2005 to $25 \%$ in 2050 . The existing nuclear power plants in Temelin and Dukovany - which are actually supplied with Russian fuel - will help to achieve this goal. ${ }^{47}$

\footnotetext{
47 Energy Policies of IEA Countries - Czech Republic - 2010 Review.
} 
The Czech Republic forecasts that the share of fossil fuels in the production of electrical energy will fall from $37 \%$ to $18 \%$ by 2050 . Czechs are not concerned about public acceptance of nuclear power in Central-European Union as the support for this source of energy in their country is growing. $34 \%$ of the European Union society is in favour of the reduction of nuclear power's share in the overall energy balance, whereas only $20 \%$ of Czechs think the same. Only several per cent of EU citizens support the concept of increasing atom's share of energy creation, whereas 30\% of Czech people strongly favour this idea. There is a growing support for the construction of new nuclear reactors in Temelin. It has already reached the level of $70 \%$. The third and fourth reactors in Temelin are expected to be operational in around 2020-2025 at the earliest. The mix of nuclear power, renewable energy sources and fossil fuels will be required for energy decarbonisation. Moreover, research is being done on clean coal technologies, such as coal gasification as well as carbon dioxide capture and storage - they are still very expensive, though.

The situation and the strategy presented above make Czechs feel no concern about their cooperation with Russia or Germany. Regardless of their loyal membership in the Visegrad Group and their energy programmes, Czechs do not get involved in conflict areas, because they can avoid it thanks to having access to alternative sources of energy supply.

Slovakia is in a much worse situation because it almost wholly depends on Russian gas imports (just like Estonia and Latvia), and its coal reserves are a lot scarcer. Thus, it is much more sensitive to the influence of external conditions regarding energy issues. The convenient location of the Czech Republic becomes obvious when compared to the situation of Slovakia. However, Slovakia has one significant advantage over its western neighbour - almost 56\% of electrical energy in this country comes from nuclear power plants, which puts Slovakia on the $3^{\text {rd }}$ position in Europe, after France (80\%) and Lithuania (78.5\%). ${ }^{48}$

48 Nuclear sources contribute only $17 \%$ to total electricity generation in the world. Jurgis Vilemas, Energy Policy of Lithuania in 1990-2010 and Projections for the Future, "International Association for Energy Economics" 2010, vol. 4, p. 24. 
Russia is Slovakia's third biggest trade partner, following Germany and the Czech Republic. The two countries have signed over 70 intergovernmental and interministerial agreements. The specific nature of their cooperation is reflected in the fact that Russia "... modernized jet fighters MIG-29 of the Slovak air forces, and then it customized them to meet NATO standards." 49 Yet, Slovakia does not view energy cooperation with Russia as a threat to its sovereignty.

On April 7, 2010, the Slovak gas company SPP agreed with its Russian supplier Gazprom that contracted yearly volumes of gas will be temporarily decreased and will be increased in later years. At the same time, SPP decided to withdraw its suit against Gazprom, in which it sought compensation for losses caused by the gas-transit crisis of early 2009, from international arbitrage in Paris. SPP was the only gas company that used lawsuit as a negotiation tool for exerting pressure on the Russian side. The agreement between SPP (controlled by the government of Slovakia, but managed mainly by the consortium of the German E.ON and Gaz de France) and the Russian Gazprom envisages 10\% reduction of gas received by the Slovak company as was stated in the long-term contract. Within the next four years the volumes of imported gas will increase by $5 \%$ compared to the initial level. Thanks to the agreement, SPP will avoid paying contractual fines resulting from a "take or pay" close. It must be emphasized that it is quite a rare thing to achieve such a successful outcome in negotiations with Gazprom..$^{50}$

To describe relations of Lithuania, Latvia and Estonia with Russia in one sentence, it should be pointed out that they are marked by complex and multidimensional dependence of these countries on Russia. All three Baltic States are 100\% dependent on gas and oil imports from Russia. Therefore, their situation is difficult. Only Lithuania is less sensitive to potential Russian manipulations with gas and oil imports, because $80 \%$ of its electricity is received from nuclear energy. Moreover, being a transit country between Russia and the Kaliningrad Oblast, it gains a trump card

49 M. Raś, Polityka Rosji wobec Europy Środowo-Wschodniej, Prace Instytutu Europy Środkowo-Wschodniej, Lublin 2010, p. 42.

50 www.osw.waw.pl. 
in the economic and strategic dialogue with Russia. Neither Latvia nor Estonia has such an asset. ${ }^{51}$

After regaining independence, the Baltic States significantly reduced their dependence on Russian supplies. Estonia decreased its dependence on Russia as the sole supplier of all energy types from $90 \%$ to $21 \%$, Latvia to $29 \%$, and Lithuania to $46 \% .{ }^{52}$ The Baltic states firmly believe that their energy security relies on joint cooperation with EU and NATO countries, on their ability to establish a joint position when negotiating terms of long-term contracts for gas and oil supply from Russia, and on transparency of the principles and conditions included in these contracts, in order to prevent Russian companies and the Russian government from treating their European customers in a different way.

Only after their accession to the European Union did Russia stop forcing the Baltic states to double tax their export commodities, which strengthened trade surplus on the Russian side. That was the case of Estonia, for which Russia was the fourth biggest trade partner by mutual trade volume in 2009. In 2004, Estonia still ran huge deficit in its trade with Russia (the export-import ratio was 1:2.1). In 2009, the balance of trade between the two countries was almost equal (for details: see the table below). Many countries which import oil and gas from Russia could envy Estonia. The strategy is fairly simple - Estonians are steadily building their independence by pursuing the policy of equal trade balance with Russia.

\section{The balance of trade between Estonia and Russia 2000-2009} (millions euro)

$\begin{array}{rrr} & \text { Export } & \text { Import } \\ \mathbf{2 0 0 0} & 81.7 & 391.3 \\ \mathbf{2 0 0 1} & 101.4 & 389.6 \\ \mathbf{2 0 0 2} & 121.5 & 375.1 \\ \mathbf{2 0 0 3} & 155.9 & 491.3\end{array}$

51 I. Pasukeviciute, M. Roe, The Politics of Oil in Lithuania: Strategies after Transition, "Energy Policy" 2001, No. 29.

52 I. Oldberg, Reluctant Rapprochment: Russia and the Baltic States in the Context of NATO and EU Enlargements, The Swedish Defence Research Agency FOI, Stockholm 2003, p. 55. 


$\begin{array}{rrr} & \text { Export } & \text { Import } \\ 2004 & 268.4 & 619.8 \\ 2005 & 396.3 & 715.8 \\ 2006 & 607.2 & 1386.9 \\ 2007 & 703.0 & 1150.0 \\ 2008 & 882.0 & 831.0 \\ 2009 & 600.0 & 639.0\end{array}$

Source: The Statistical Office of Estonia.

All Baltic States are dissatisfied with the fact that they have to pay the highest prices in the European Union for Russian gas. In winter 2010, they imported gas at \$315-330 per 1000 cubic metres, whereas the price for Western European consumers was \$265-270. After tough negotiations in December 2010, it was agreed that the price of natural gas for Estonia would be $11 \%$ lower in January 2011 than a year before. It shows that Russians have made a slight concession, but the price level for Estonia remains higher than the average price level for the European Union countries. The 2010 National Security Concept for Estonia recognizes the risk connected with the isolation of electricity and gas supply from the European interconnected energy networks..$^{53}$ It does not indicate, however, price manipulations of the Russian monopolist as a threat to Estonia.

Latvia's guidelines for Energy Sector Development 2007-2016, adopted by the government on June 27, 2006, have to face high monopolization of the energy market in this country - over $90 \%$ of electrical energy is produced and sold by one company, Latvenergo; and a single company, Latvijas Gaze, performs all functions (production, distribution, storage, selling and supply) in the gas market. The system is not connected physically or legally to energy networks of the European Union, which would require huge investment. Thus, it will be difficult for Estonia to implement diversification, which is the basis of secure supplies. It seems that Latvians will need more time than Lithuanians to adapt their law to energy regulations of the European Union. ${ }^{54}$

53 National Security Concept of Estonia, May 2010, p. 8, www.eesti.ee.

54 www.em.gov.lv, accessed on January 21, 2011. 
The process of reducing dependence of the Baltic states on Russia is not easy not only because of communist heritage in the institutional sphere of energy markets, such as the situation in Estonia. Another type of problems appeared when Lithuania tried to negotiate discounts on the highest prices for gas in Europe paid to Russia. Latvia and Estonia will pay the reduced price for gas from the beginning of 2011. Lithuania cannot count on a similar discount. The Lithuanian government believes that it is a punitive step against Lithuania for its highly advanced plans for the introduction of the so called EU's Third Energy Package, which obliges all member states to divide energy concerns according to their business activities. In accordance with the EU regulations, an oil producer cannot hold shares in the company which transports this oil. The Lithuanian authorities have made necessary amendments to the natural gas law and have made a decision to divide the Lithuanian oil concern Lietuvos Dujos (Gazprom own $37 \%$ of its shares) into two separate companies. The division is expected to be completed by March 2012. This clause of the Third Package is particularly painful for Gazprom and oil companies from Russia, which often use such monopolistic practices. In his letter of January 4, 2011, the European Commissioner for Energy, G. Oettinger, expressed his support for Lithuania's Energy Independence Strategy, which is based on two premises: firstly, the construction of a nuclear power plant in Lithuania within the broader framework of the Baltic Energy Market Interconnection Plan (BEMIP), and, secondly, on introducing the Third Package. ${ }^{55}$ The Strategy includes the plan of interconnecting Polish and Lithuanian energy networks by 2016 and gas networks of these countries by 2018-2020.

\section{FINALLY, POLAND}

The structure of imports from Russia to Poland has always been dominated by mineral products, including crude oil and natural gas. This group of commodities accounts for $73.5 \%$ of Polish imports from Russia. Poland is a significant importer of Russian natural gas and crude oil, which

55 www.enmin.lt, accessed on 4.01.2011. 
allows Russia to maintain permanent surplus in the balance of trade with Poland.

On October 29, 2010, Polish Deputy Prime Minister and the Minister of Energy, Waldemar Pawlak, and his Russian counterpart, Igor Sechin, signed a long-delayed deal that will increase imports of gas from Russia. Under the deal, Poland's annual imports of Russian gas will rise from 7.5 billion cubic metres to more than 9 billion cubic metres in 2011 and to about 10 billion cubic metres from 2012 through 2022. Poland is under pressure from Gazprom as almost $92 \%$ of its gas imports come from Russia. The agreement to change the shareholding structure of EuRoPolGAZ the operator of the Polish stretch of the Yamal pipeline was signed.

"In order to improve Poland's energy security, two diversification projects need to be implemented. The first of them is the construction of the LNG terminal for the off-take of liquefied natural gas (LNG) in Świnoujście. The terminal will enable the re-gasification of 2.5-7.5 billion cubic metres of natural gas annually. The other project is the Baltic Pipe, the underwater pipeline that will link the Polish distribution grid with the Danish one, thanks to which Poland will be able to receive $2.5-3$ billion cubic metres of gas from the Norwegian continental shelf." ${ }^{56}$ The contract put Poland into the select group of Gazprom's customers. Only in the years 2006-2007, Gazprom signed a few spectacular long-term agreements. The German E.ON extended current contracts for natural gas supplies by 15 years (from 2020 to 2035). Under the contracts, annual supplies of gas will amount to about 20 billion cubic metres. The German company will additionally receive 4 billion cubic metres of natural gas The Italian ENI signed a contract for the supply of 22 billion cubic metres in 2017-2035. It also enabled Gazprom's subsidiaries to enter the Italian retail market in return for a substantial chunk of shares in gas fields in the Russian Federation. The French Gaz de France will receive 12 billion cubic metres annually of natural gas from Russia in 2012-2030, with an option to receive another 2.5 billion cubic metres from the North European Gas Pipeline. The French also allowed Gazprom to enter their retail market. A similar contract for supplies of 7 billion cubic metres of natural gas,

56 J. Kowalski, Europa w kleszczach Gazpromu, "Nowe Państwo” 2009. 
with an annex which gave Gazprom the right to sell gas to retails customers, was signed in Austria, as well as in Denmark, the Czech Republic, Romania, and Bulgaria. By 2030, almost $84 \%$ of EU gas imports are expected to come from Russia.

The conflict between Poland and Lithuania over PKN Orlen operations in Lithuania is an example of how Russia exerts hidden influence on tensions and disputes among the countries of the ABB10 group. The Polish oil concern PKN Orlen acquired the controlling stake in the Mažeikiai refinery in the middle of December 2006 - it purchased 53.7\% of shares for $\$ 1.49$ billion from Yukos International UK B.V. , and 30.66\% shares for $\$ 852$ million from Lithuania's government. On more than one occasion the directors of PKN Orlen complained that Yukos International had presented incomplete information about the condition of the refinery. Hence, PKN Orlen submitted updated \$250 million compensation claim against Yukos International regarding the purchase. The initial claim was filed on July 15, 2009 in the Court of Arbitration at the International Chamber of Commerce. In 2006, the Russian Transneft suspended oil supplies to the Mažeikiai refinery, justifying this decision with a failure in the section of the Druzhba pipeline which transmits Russian oil to the refinery taken over by PKN Orlen. Therefore, oil has to be delivered to the Orlen Lietuva refinery by tankers and rail. Moreover, in 2008, Lithuania's state-owned railway company, Lietuvos Gelezinkeliai, closed the railway line which was used by PKN Orlen for transporting oil from its refinery in Mažeikiai. Despite conciliation efforts of Lithuanian Prime Minister Kubilius, the debate continues and even court adjudications in Orlen's favour do not prevent Lithuanian railway from doing economic harm to the Polish company. In spite of those problems of PKN Orlen in Lithuania, the cooperation between the two countries is still developing, mainly on the initiative of Poland.

The Polish pipeline operator Gaz-System says it is keen to build a pipeline to Lithuania, provided the European Union is willing to cover some of the costs, which are estimated at 1 billion zloty. The European Commission would have to subsidize the Polish-Lithuanian project with at least 100 million euro. Brussels has already financed the feasibility study, and the investment was backed by Jose Manuel Barrosso as it would help 
Lithuania to gain partial independence from Russian supplies. Lithuanians are in an extremely inconvenient situation as regards gas imports, and Gazprom owns shares in Lietuvos Dujos. ${ }^{57}$

In June 2010, on Poland's initiative the organization of Central Europe Energy Partners (CEEP) was founded. The main targets of this international organization, bringing together entrepreneurs from Central Europe with a representation in Brussels, are:

- to lobby for the reduction of differences between the EU's old and new member states;

- to actively participate in the EU's activities in the field of energy;

- to initiate legislative solutions in this sector.

There are about two thousand lobby groups from the "old" Union and just a few from the countries of Central Europe. The CEEP's next task will be to identify - together with energy enterprises from Lithuania, Latvia, Estonia, the Czech Republic, Slovakia, Bulgaria, Hungary and Romania ten most important issues which the European Union should deal with and to come out with specific proposals how to solve them.

In June 2010, the Inter-Parliamentary Assembly of Poland, Lithuania and Ukraine debated over energy security. The MPs recognized the need for diversification of energy sources and agreed that the Odessa-BrodyPłock-Gdańsk pipeline must be built as soon as possible. ${ }^{58}$ The pipeline would be used for transporting oil from the Caspian Sea to Europe. The inaugural session of the Assembly was held in June 2008 in Kiev in Ukraine. The second meeting, on the initiative of Bogdan Borusewicz, Senate Speaker of Poland, was held a year later in Lublin, to commemorate the $440^{\text {th }}$ anniversary of founding the Union of Lublin, the pact between Poland and Lithuania that united the two countries into a single state.

57 Gaz-System has also received European grants under the Operational Programme Infrastructure and Environment 2007-2013 to develop other pipeline projects as well as to provide financial support to the construction of LNG terminal in Świnoujście. GazSystem is also interested in building a gas pipeline to Slovakia, which could form a part of the whole "North-South gas corridor."

58 Russia will stop supplying crude oil to the Odessa-Brody pipeline, November 11, 2010, www.rp.pl. If this information is confirmed, parliamentary initiatives on this issue will become pointless. 


\section{CONCLUSIONS}

- By 2030, almost $84 \%$ of EU gas imports are expected to come from Russia. At present, Russian natural gas accounts for $100 \%$ of imports of Finland, Estonia, Lithuania, Latvia, Slovakia, Slovenia, over $90 \%$ - Poland, $85 \%$ - Greece, $80 \%$ - Hungary, $75 \%$ - the Czech Republic, 70\% - Austria, 35\% - Italy, almost 30\% - Germany and $25 \%$ - France. However, Russian gas mains are located on the route from east to west, which means mutual dependence of Europe and Russia. The only alternative consumer of Russian gas could be China, but it cannot afford to pay European prices. ${ }^{59}$

- There is no direct relation between strong dependence on energy imports from Russia and the kind of strategic orientation towards this country. The countries which are heavily dependent on gas imports from Russia (Estonia, Latvia, Lithuania and Slovakia from ABB10 group) have unfriendly attitude towards the Russian Federation, ${ }^{60}$ whereas Finland and Bulgaria, which also rely on Russian supplies, look much more favourably on their great partner.

- Generally speaking, the countries of the ABB10 group are a lot more dependent on supplies of energy carriers than the old countries of the European Union. They are also typically more hostile towards Russia. The reason for this is that the ABB10 countries used to be politically and militarily dependent on the Soviet Union and painful memory of those times remains. Moreover, they were a lot more affected by Russia's policy of restrictions and imposed conditions in the sphere of energy after joining Western political and economic structures.

- The countries of the ABB10 group are quite successful in the actions they take in response to Russia's expansive and offensive energy strategy. They do not restrict themselves to self-defence, but they make the European Union join the energy debate with Russia. The Union is becoming an increasingly active player in this strategic game.

\footnotetext{
59 Based on J. Kowalski, op.cit

60 S., Charlotte, Ekonomi och säkerhet $i$ de baltiska staterna: en studie av relationen mellansäkerhetstänkande och ekonomiska beroenden, FOI, Stockholm 2003.
} 
- Shale gas is an obvious alternative to natural gas from Russia for the $\mathrm{ABB} 10$ region. Geologists claim that there are shale gas reserves of 2.2 trillion cubic metres in the area of Lower Saxony and North Rhine-Westphalia (the north-west part of Germany), whereas Poland may have 1.4 trillion cubic metres of reserves. Ukraine has also announced the discovery of affluent shale gas deposits. As Russia participates in the joint Nord Stream project with EU countries, it may decide to abandon gas transit via Poland (at present, about $20 \%$ of Russian gas exports to Europe go through Poland).

- Western structures, to which the ABB10 countries presently belong, are also very sensitive to energy shocks as the population of NATO countries accounts for $13 \%$ of the world's population, but it consumes as much as $50 \%$ of energy generated in all forms. However, the possible use of energy as a strategic tool by Russia should not be demonized as the following energy circumstances reduce potential threats:

- Energy and its carriers may be used as a shield rather than a sword, which means that they may hinder critical and negative activities towards Russia, but it is more difficult to make them an offensive weapon.

- The long-term demand for fossil fuels is likely to decrease in Europe, including the ABB10 group, partially due to the implementation of the Europe 2020 Strategy (3x20 goals). ${ }^{61}$

- Today's world faces excess crude oil extraction capacity of a few millions barrels a day, which may account for 5-10\% of consumption and demand. Therefore, an alternative source of supply can be easily found.

- Russia - as the state and its energy companies - is so much dependent on the revenue from energy exports to the European Union that it cannot afford to play its energy card in an irrational and unreasonable way. It is the functional interdependence rather than the dominance of one side of energy transactions.

61 T. Mitrova, Energy Markets in a Turbulent Zone: Russia in Need of a New Strategy, "Russia in Global Affairs", July-September 2009, vol. 7, No. 3 Obama administration's policy also pursues stabilization of the level of energy consumption in the United States by 2020. 